\title{
Analisis Pendidikan Karakter Melalui Budaya Sekolah di Kelas 3 Madrasah Ibtidaiyah
}

\author{
Fera Susilo $^{1 凶}{ }^{\bowtie}$ Zaka Hadikusuma Ramadan $^{1}$ \\ Pendidikan Guru Sekolah Dasar, Universitas Islam Riau, Indonesia(1) \\ DOI: $10.31004 /$ obsesi.v6i3.1950
}

\begin{abstract}
Abstrak
Implementasi pendidikan karakter di sekolah dasar dilaporkan sejumlah studi terdahulu belum berjalan sesuai dengan tujuan yang diharapkan. Teori dan praktik bagaimana merancang program belajar yang mengintegrasikan pendidikan karakter belum sepenuhnya dikuasai oleh guru sebagai pemegang peran utama terlaksananya pendidikan karakter di sekolah. Melalui pendekatan deskriptif, studi ini bertujuan untuk memperoleh informasi tentang penerapan pendidikan karakter di sekolah. Guru, kepala, sekolah, dan siswa kelas tiga sekolah dasar menjadi partisipan dalam penelitian ini. Data yang diperoleh dari teknik wawancara, observasi, dan dokumentasi kemudian dianalisis menggunakan triangulasi metode. Hasilnya, diperoleh tiga tema yang menjadi fokus utama implementasi pendidikan karakter melalui budaya sekolah. Tema tersebut adalah: 1) program Jumat Berkah sebagai salah satu budaya sekolah untuk menanamkan karakter, 2) nilai karakter yang tampak pada siswa madrasah ibtidaiyah, 3) hambatan pelaksanaan program. Implikasi hasil penelitian ini dapat digunakan oleh guru sebagai referensi penyusunan program pendidikan karakter di sekolah.
\end{abstract}

Kata Kunci: pendidikan karakter; siswa kelas 3 sd; budaya sekolah

\begin{abstract}
The implementation of character education in primary school had been reported by previous studies did not run appropriately with the aims yet. Theories and practices on how to design the learning program integrating character education had not been mastered by the teacher as the key role of character education at school. By descriptive approach, this study aimed to get information about the implementation of character education at school. Teacher, principal, and third-grade students involved in this study. Data from the interview, observation, and documentation were analyzed using method triangulation. The result is three themes emerged: 1) Jumat berkah program as one of the school cultures for implementing character education, 2) character value that visible to students, and 3) the challenge. The implication of this study can be used by the teacher as a reference to design the character education.
\end{abstract}

Keywords: character education, third-grade students, school culture

Copyright (c) 2021 Fera Susilo, Zaka Hadikusuma Ramadan

$\triangle$ Corresponding author :

Email Address : verasusilo08@gmail.com (Pekanbaru, Indonesia)

Received 15 July 2021, Accepted 22 November 2021, Published 22 November 2021 


\section{PENDAHULUAN}

Karakter memiliki arti umum sebagai suatu sikap manusia terhadap lingkungan sehingga seseorang bertindak dengan menampilkan kesukaan di hadapan orang lain pada nilai-nilai kebenaran (Furkan, 2013). Penanaman nilai karakter memerlukan interaksi yang baik dengan cara melakukan pendekatan pada pesera didik sehingga dapat dipahami serta dilaksanakan kemanapun siswa itu berada. Proses ini diawali dari keluarga, kemudian dilanjutkan dengan sekolah, dan komunitas yang diikuti anak usia dini tersebut (Prasanti \& Fitrianti, 2018). Lingkungan itulah yang nantinya akan membentuk kepribadian anak sebagai ciri khas karakternya. Bagaimana anak berfikir, bertindak, dan mengungkapkan pendapat akan dipengaruhi oleh bagaimana lingkungan memberinya contoh dan umpan balik. Kesuksesan orangtua membimbing anak mengatasi konflik kepribadian dan perilaku sesuai dengan tahap perkembangan psikososialnya akan menentukan kesuksesan anak dalam kehidupan sosial di masa dewasa. Jika di rumah orangtualah yang menjadi pengontrol perilaku anak, maka ketika anak di sekolah gurulah yang menjadi penggantinya. Guru sebagai orangtua kedua anak ketika di sekolah dapat menerapkan pendidikan karakter sesuai dengan prioritas pemerintah Indonesia pada pembangunan nasional sebagaimana yang dituangkan dalam Rencana Pembangunan Jangka Panjang (RPJP) Nasional Tahun 2005 - 2025 (Undang-Undang No.17 Tahun 2017) yang berisi mewujudkan masyarakat yang berakhlak mulia, bermoral, beretika, berbudaya, dan beradab berdasarkan falsafah Pancasila.

Berdasarkan RPJP di atas dapat diketahui bahwa pendidikan tidak sekedar mengembangkan potensi dan pengetahuan saja. Pendidikan juga berorientasi pada penerapan nilai karakter sehingga peserta didik mampu mengenali dirinya dan membiasakan segala sesuatu dengan keadaan di sekitarnya melalui kegiatan di sekolah (Norianda et al., 2021). Sekolah perlu mengembangkan nilai-nilai karakter yang telah terkikis dalam diri manusia dan membangun prilaku baik dan rasa percaya diri untuk membawa perubahan (Rahmawati, 2017a). Nilai karakter yang perlu diterapkan pada anak usia sekolah dasar seperti tidak egois, baik hati, cinta kedamaian, keberanian, mandiri, displin, suka mengembangkan potensi, rasa keadilan dan memiliki rasa kasih sayang (Maesyaroh, 2018). Lebih jauh, pendidikan karakter dapat menjadi dasar bagi suatu bangsa untuk memiliki nilai seperti kejujuran,cinta tanah air, tidak egois, baik hati dan disiplin (Alfajar, 2014). Penanaman nilai tersebut dapat dilakukan dengan cara memberi contoh secara langsung. Hal ini karena anak sekolah dasar di awali dengan fase berfikir oprasional kongkrit ketika duduk di bangku kelas satu. Mereka memiliki pemikiran yang terbatas pada obyek konkret atau nyata sehingga dalam pendidikan karakter mereka harus melihat perilaku mana yang sesuai untuk dilakukan secara langsung (Kurniawan, 2017).

Sayangnya, penelitian terdahulu melaporkan bahwa implementasi pendidikan karakter yang tercantum dalam kurikulum 2013 di sekolah dasar masih saja mengalami kendala (Muhtar \& Dallyono, 2020). Kurangnya pelatihan yang diberikan pada guru tentang cara mengintegrasikan pendidikan karakter dalam sebuah mata pelajaran, cara menginternalisasi nilai karakter yang masih bercabang-cabang tidak terintegrasi dengan baik, dan kurangnya pihak yang expert atau ahli dibidangnya menjadi beberapa penyebab implementasi pendidikan belum maksimal. Dari permasalahan tersebut, dapat diketahui bahwa guru menjadi faktor utama dalam perubahan perilaku anak. Guru perlu mendesain program belajar yang mengintegrasikan karakter dalam kehidupan keseharian siswa seperti mengintegrasikan nilai sosial dan religius dalam berbagai mata pelajaran. Meskipun hanya dengan metode ceramah tentang moral yang disisipkan dalam pembelajaran, tetap akan berpengaruh pada pandangan, pemahaman, dan keyakinan siswa. Lebih lanjut, integrasi keluarga dan masyarakat perlu dilibatkan dalam program tersebut. Proses ini membutuhkan waktu yang panjang, berkelanjutan, dan berlangsung seumur hidup. Oleh karena itu, dibutuhkan kesabaran dan kekonsistenan guru agar dapat dicontoh oleh siswa.

Lebih jauh, sebuah studi yang menyatakan bahwa guru belum memiliki pemahaman yang jelas tentang teori dan praktik bagaimana merancang program belajar yang 
mengintegrasikan pendidikan karakter (Jhon et al., 2021). Kondisi ini menunjukkan belum semua guru memperoleh pelatihan yang tepat dimana mereka bisa memperoleh informasi, berbagi, dan mendiskusikan berbagai permasalahan terkait pendidikan karakter. Akibatnya guru lebih fokus pada materi pembelajaran daripada pembentukan perilaku. Pembelajaran di sekolah akan menekankan pada pengetahuan atau konsep dengan atau bahkan tanpa adanya integrasi nilai yang sesuai. Sebagai contoh, pada pembelajaran matematika mereka diajarkan bagaimana cara membagi empat kue, menjumlahkan dua kue, dan mengurangkan empat kue untuk dua anak. Hasilnya adalah anak memiliki pemahaman yang bagus untuk operasi hitungan, namun mereka tidak dapat menunjukkan karakter yang positif ketika ada teman yang pada hari itu lupa membawa bekal makanan sementara ia punya dua bekal. Lebih jauh, kurang atau bahkan tidak adanya asesmen yang berkaitan dengan perilaku anak di sekolah dasar menyebabkan pendidikan karakter dikesampingkan oleh guru.

Pendidikan karakter dapat dibangun melalui pelaksanaan budaya sekolah yang dapat dikembangkan dari nilai agama dan sosial, pengembangan sarana dan prasarana, bentuk visi dan misi, tata tertib biagi guru dan siswa, budaya 5s ( senyum, sapa, salam, sopan, santun) budaya disiplin, budaya kerja keras, budaya tanggung jawab, budaya hidup sehat, dan budaya santun bahasa (Rahayu \& Taufiq, 2020). Budaya mencerminkan perilaku, tradisi, kebiasaan yang dijalani di kehidupan sehari-hari yang di terapkan dalam lingkungan sekolah dijalankan oleh guru dan siswa berulang ulang kali sehingga menjadi kebudayaan (Arifin, 2019). Jika sudah diterapkan dan wajib dilakukan di sekolah, maka budaya dapat menjadi peraturan turun temurun pada setiap anggota baru (Lusyanti et al., 2020). Pada awalnya mungkin anak kelas satu SD yang baru saja mulai mengikuti pelaksanaan budaya sekolah akan terlihat bingung, namun seiring keberlangsungan kegiatan tersebut dilaksanakan ia akan mengerti bagaimana cara melakukannya dan untuk apa hal tesebut dilakukan. Kondisi yang konsisten terhadap pelaksanaan budaya sekolah dapat mempermudah siswa memiliki karakter yang baik (Suhadisiwi, 2018).

Implementasi pendidikan karakter melalui budaya sekolah dilaporkan oleh studi terdahulu yang menyatakan bahwa dapat dilakukan melalui kegiatan intrakulikuler dan ekstrakulikuler. Kegiatan intrakulikuler melalui pembiasaan 5S (senyum, sapa, salam, sopan, dan santun), tadarus klasikal, senam masal, pemilahan sampah, upacara bendera, memperingati hari besar, dan kunjungan ke perpustakaan (Agustini, 2015; Anggraini, 2017). Sedangkan untuk kegiatan ekstrakulikuler melalui pramuka, membatik, TPA, TIK, drumband, karate, gamelan, tari, dan atletik. Setiap kegiatan baik intakulikuler maupun ektrakulikuler mengandung nilai karakter yang dapat dipelajari oleh siswa. Sebagai contoh, membatik mengajarkan pada anak bagaimana cara untuk bertanggungjawab terhadap kelestarian budaya bangsa. Pemilahan sampah mengajarkan pada anak untuk mencintai lingkungan alam, menggunakan benda yang dapat didaur ulang, dan membedakan mana sampah yang dapat digunakan kembali dan mana yang tidak. Kooperatif dilakukan dengan mengajak orangtua ikut serta dalam mengembangkan dan memperkaya kegiatan program sekolah. Mereka diberi kesempatan untuk ikut berpendapat dan mengeluarkan idenya. Ukhuwah dilakukan dengan menjalin persaudaraan diantra guru dan karyawan di sekolah. Setiap civitas wajib untuk mengenal satu sama lain, memahami karakter, saling membantu, dan menunaikan hak dan kewajibannya. Terakhir, berorientasi pada mutu merujuk pada perencanaan strategis yang jelas mengarah pada pembentukan karakter dan pencapaian kompetensi peserta didik.

Selanjutnya, studi terdahulu juga menyatakan bahwa budaya sekolah yang dikembangkan dalam rangka penanaman karakter dilakukan melalui pengembangan model kurikulum pendidikan karakter berbasis budaya sekolah (Khairudin, 2013). Model pendidikan ini melibatkan seluruh civitas akademika di sekolah termasuk petugas keamanan, UKS, dan kebersihan. Penanaman karakter dalam kurikulum dilakukan melalui kegiatan yang integratif, produktif, qudwah khasanah, kooperatif, ukhuwah, kebersihan, dan berorientasi pada mutu. Secara terintegrasi, proses pembelajaran dilakukan dengan memadukan nilai-nilai 
agama dengan nilai ilmu pengetahuan umum. Kegiatan produktif dilakukan dengan cara memotivasi belajar siswa dengan berbagai metode dan strategi pembelajaran serta menggunakan sumber dan media belajar. Qudwah khasanah dilakukan dengan cara orang dewasa menjadi contoh bagi anak untuk memiliki sikap amanah, komitmen tinggi, disiplin, antusias, motivasi tinggi, peduli, dan menghargai orang lain.

Pembiasaan seperti kegiatan rutin yang dilakukan secara konsisten dan terus menerus setiap saat, kegiatan spontan, dan pengondisian keterlaksanaan pendidikan karakter juga dapat dilakukan oleh sekolah untuk menanamkan nilai-nilai moral, sosial, dan agama pada anak (Riadi, 2018). Kegiatan yang konsisten biasanya terjadwal, bisa dilakukan setiap hari, seminggu sekali, atau dalam periode tertentu. Sebagai contoh, berdoa sebelum dan sesudah belajar, mengucapkan salam apabila bertemu guru, dan berbaris ketika masuk kelas. Kegiatan spontan dilakukan ketika ada peristiwa yang tidak terduga sebelumnya seperti ada teman yang terkena musibah atau masyarakat yang terkena bencana. Anak-anak diminta untuk membawa sumbangan dari rumah bisa berupa uang, sembako, atau pakaian. Kemudian, pengkondisian berkaitan dengan kebersihan dan ketersediaan sarana prasarana di sekolah.

Pelaksanaan pendidikan karakter di sekolah dasar tidak semudah memberikan pembelajaran pengetahuan umum. Berbagai kendala atau hambatan masih ditemui oleh guru sebagai pihak yang mendesain dan mengimplementasikan pendidikan karakter anak. Banyak yang merasa bingung dari mana mereka harus mulai mengintegrasikan pendidikan karakter dalam sebuah mata pelajaran atau kegiatan sekolah. Solusi permasalahan dari berbagai kondisi tersebut salah satunya adalah implementasi pendidikan karakter melalui budaya sekolah. Beberapa studi terdahulu telah menggambarkan bagaimana proses budaya sekolah untuk menanamkan karakter pada anak di sekolah dasar negeri, sekolah unggulan, dan sekolah berbasis islam terpadu (Agustini, 2015; Anggraini, 2017; Khairudin, 2013; Riadi, 2018). Akan tetapi, studi tentang budaya karakter di sekolah dasar dengan jenis madrasah ibtidaiyah masih sangat terbatas. Hal inilah yang menjadi kabaharuan dalam penelitian ini karena madrasah ibtidaiyah memiliki orientasi pembelajaran yang sedikit berbeda dengan sekolah dasar. Sekolah jenis ini biasanya lebih menekankan pada pembentukan jati diri, karakter, dan kepribadian islami (akhlakul kharimah) dengan tidak mengesampingkan ilmu pengetahuan dan teknologi. Jadwal pembelajaran untuk pendidikan umum sama dengan pendidikan agama. Kondisi ini tentu berbeda dengan sekolah dasar negeri yang mengunggulkan pencapaian prestasi akademik dengan penanaman nilai yang lebih sedikit. Perbedaan proses pembelajaran ini dapat memberikan dampak yang berbeda pada berbagai nilai karakter yang dimiliki anak. Oleh karena itu, penelitian ini bertujuan untuk menggambarkan pendidikan karakter melalui budaya sekolah di madrasah ibtidaiyah.

\section{METODOLOGI}

Penelitian ini menggunakan jenis penelitian kualitatif dengan menggunakan pendekatan deskriptif. Metode penelitian ini dipilih karena peneliti ingin memperoleh data yang dapat menggambarkan strategi pelaksanaan budaya sekolah sehingga dapat mempermudah pengimplementasian pendidikan karakter. Data yang akan diperoleh didasarkan pada peristiwa yang sudah terjadi di lapangan tanpa diberikan suatu perlakuan atau perubahan. Subyek penelitian ini terdiri dari kepala sekolah, guru, siswa kelas III (usia sekitar 8-9 tahun). Teknik pengambilan data dilakukan dengan tekik purposive sampling dengan pertimbangan bahwa anak usia kelas tiga berada di tingkat peralihan dari kelas rendah ke kelas atas. Lokasi pengambilan data berada di Madrasah Ibtidaiyah Hubbul Wathan Petai. Sebelum dilakukan penelitian, kami meminta ijin terlebih dahulu kepada kepala sekolah. Tujuan, fokus, dan subyek yang dibutuhkan disampaikan secara rinci. Kemudian, surat ijin penelitian dan surat ijin observasi juga diberikan untuk melengkapi urusan administrasi.

Sekolah ini dipilih karena salah satu budaya yang dilakukan sekolah adalah adanya program Jumat Berkah. Program ini jika digambarkan lebih rinci dapat menjadi pandangan 
atau bahkan pedoman bagi sekolah dasar lain untuk menerapkan pendidikan karakter. Teknik pengambilan data menggunakan wawancara, observasi, dan dokumentasi. Wawancara dilakukan kepada kepala sekolah, guru, dan siswa. Setelah itu, observasi dilakukan untuk mencocokkan data yang diperoleh dari hasil wawancara dengan implementasinya. Observasi dilakukan ketika seluruh anak, guru, dan karyawan melakukan budaya sekolah. Sedangkan dokumentasi diperoleh dari sarana prasarana yang mendukung implementasi budaya sekolah. Setiap teknik pengambilan data memiliki instrumen yang digunakan oleh peneliti sebagai pedoman ketika di lapangan (lihat Tabel 1). Oleh karena itu, data diperoleh secara menyeluruh dan tidak jauh dari tujuan penelitian.

Tabel 1. Pedoman Wawancara

\begin{tabular}{ll}
\hline No & Indikator \\
\hline $\mathbf{1}$ & Apakah sekolah sudah menerapakan pendidikan karakter? \\
$\mathbf{2}$ & Program apa yang digunakan sekolah untuk menerapkan pendidikan karakter? \\
$\mathbf{3}$ & Nilai karakter apa yang terintegrasi dalam program tersebut? \\
$\mathbf{4}$ & Adakah hambatan dalam pelaksanaannya? \\
\hline
\end{tabular}

Tabel 2. Pedoman Observasi

\begin{tabular}{lll}
\hline No & Aspek Pengamatan & \multicolumn{1}{c}{ Objek Yang Diamati } \\
\hline $\mathbf{1}$ & Sikap tanggungjawab & Mengamati kegatan-kegiatan seluruh warga sekolah \\
$\mathbf{2}$ & Sikap membantu oranglain & dalam pelaksanaan pendidikan karakter melalui \\
$\mathbf{3}$ & Sikap memiliki kemandirian & budaya sekolah, terutama ketika program Jumat \\
$\mathbf{4}$ & Sikap peduli lingkungan & Berkah dilakukan \\
\hline
\end{tabular}

Data yang telah diperoleh dari hasil wawancara kemudian dituangkan ke dalam transkip hasil wawancara. Kemudian, proses selanjutnya adalah mereduksi data, penyajian, penarikan kesimpulan, dan verifikasi (Lihat Gambar 1). Data yang telah dituangkan dalam transkip wawancara direduksi dengan cara memilih dan memilah informasi yang diperlukan dan tidak diperlukan sesuai dengan tujuan penelitian untuk memunculkan subkategori. Subkategori yang sama kemudian diberi kode untuk mempermudah mengelompokkan ke dalam satu kategori. Kategori-kategori yang ada kemudian dirumuskan menjadi beberapa tema. Kami menggunakan triangulasi metode untuk membandingkan atau menyelaraskan antara data yang diperoleh dari hasil wawancara, observasi, dan dokumentasi. Dengan demikian, peneliti dapat memperoleh kebenaran informasi dan gambaran yang utuh mengenai informasi yang dibutuhkan.

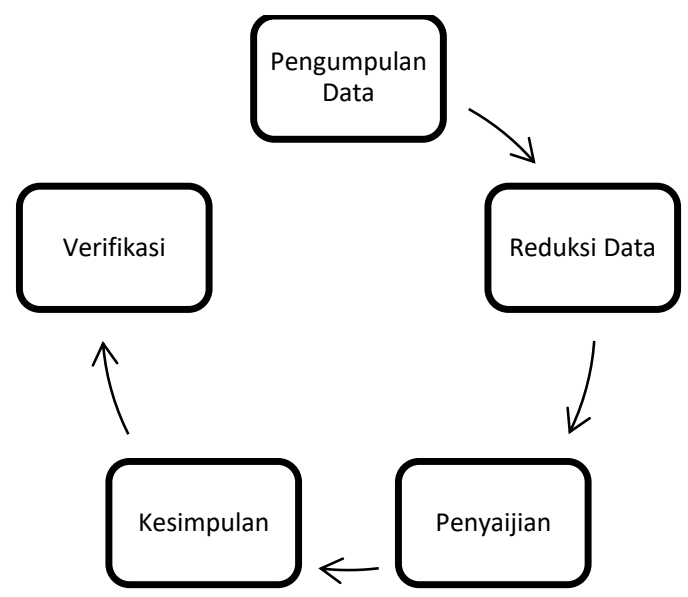

Gambar 1. Design Penelitian dan Analisis Data 


\section{HASIL DAN PEMBAHASAN}

Hasil dari analisis data menunjukkan bahwa terdapat tiga tema yang menjadi fokus utama implementasi pendidikan karakter melalui budaya sekolah. Tema tersebut adalah: 1) program Jumat Berkah sebagai salah satu budaya sekolah untuk menanamkan karakte, 2) nilai karakter yang tampak pada siswa madrasah ibtidaiyah, 3) hambatan pelaksanaan program.

\section{Program Jumat Berkah sebagai salah satu Budaya Sekolah untuk Menanamkan Karakter}

Penerapan pendidikan karakter dilakukan dengan mewujudkan penerapan visi misi sekolah dalam aktivitas siswa, perilaku, dan fasilitas sebagai pendukung secara fisik. Berdasarkan hasil observasi, budaya sekolah yang digunakan untuk menanamkan nilai tanggungjawab dan membantu oranglain adalah program jum'at berkah sebagaimana diungkapkan oleh CW 1 berikut ini.

"Siswa sudah mulai mandiri karna setiap pagi melaksanakan program jum'at berkah, sehingga sudah tahu hal apa saja yang harus di kerjakan."

Program Jumat Berkah dilakukan satu minggu sekali yakni setiap hari jumat. Kegiatan ini di pilih karena setiap kegiatanya membawa berkah dan manfaat bagi diri sendiri dan orang lain. Tidak hanya siswa tetapi juga guru wajib ikut serta dalam program tersebut. Tanpa adanya perbedaan aturan pelaksanaan budaya sekolah membuat siswa lebih mudah memahami nilai karakter karena anak meniru apa yang dilakukan orang dewasa sekitarnya. Budaya sekolah ini telah dilaksanakan sejak lama di Madrasah Ibtidaiyah Hubbul Wathan Petai. Karena sudah dilaksanakan lama, program Jumat Berkah menjadi kebudayaan di dalam sekolah tersebut. Beberapa nilai karakter yang diperoleh anak adalah nilai religius, disiplin, tanggung jawab, jujur, peduli lingkungan, mandiri. Nilai religius dan disiplin tampak pada prorgam kegiatan Jumat Sedekah, sedangkan nilai tanggungjawab, jujur, peduli lingkungan, dan mandiri tampak pada kegiatan Jumat Bersih.

Meskipun madrasah ibtidaiyah termasuk kategori sekolah formal, implementasi penanaman nilai karakter memiliki porsi waktu yang sama dengan pendidikan pengetahuan umum. Hal ini berbeda dengan hasil sebuah studi yang menyatakan bahwa pendidikan karakter lebih banyak diberikan pada anak yang mengikuti sekolah nonformal (Shohel \& Howes, 2018). Pada studi tersebut, sekolah dasar nonformal diperuntukkan bagi anak-anak yang kurang beruntung secara sosial ekonomi agar dapat memperoleh pendidikan dasar. Mereka dilaporkan memberikan lebih banyak perhatian untuk menjelaskan pentingnya berbagai perilaku baik dan buruk. Kurikulum yang mereka gunakan lebih berorientasi pada nilai-nilai kehidupan daripada kurikulum pendidikan dasar yang formal. Sementara itu, analisis kami menunjukkan bahwa sekolah madrasah ibtidaiyah yang merupakan sekolah dasar formal berupaya untuk menanamkan nilai-nilai positif tersebut. Perbedaan hasil ini bisa dijelaskan oleh fakta bahwa sekolah madrasah ibtidaiyah dalam penelitian kami sudah mengintegrasikan pendidikan karakter dalam kurikulumnya. Oleh karena itu, pendidikan karakter tidak hanya sebatas pada teori namun juga praktiknya seperti adanya program Jumat Berkah ini.

Pada hari jumat, setiap siswa dan guru wajib melakukan dua kegiatan utama yakni jum'at bersih dan jum'at sedekah. Jum'at bersih merupakan kegiatan yang dilakukan untuk memberi pengertian peserta didik tentang pentingnya menjaga lingkungan agar tetap bersih sebagaiman diungkapkan oleh CW 1 berikut ini.

"Siswa terbiasa membuang sampah pada tempatnya, sehingga kepedulian siswa sangatlah penting bagi sekolah, apalagi dalam kegiatan gotong royong siswa sangat antusias melaksanakan tugas dari guru."

Hasil ini didukung oleh penelitian terdahulu yang menyatakan bahwa jum'at bersih memberi pengertian akan pentingya kebersihan lingkungan Yudhawardhana (2017). Sekolah 
berupaya untuk tidak hanya memberikan teori tetapi juga diwujudkan dalam kehidupan sehari-hari sehingga menjadi tanggung jawab bersama. Guru bersama dengan siswa bergotong royong untuk menciptakan lingkungan yang bersih dan nyaman. Kegiatan seperti mencabut rumput, merapikan ranting pohon besar, merawat tanaman, menyapu kelas, membersihkan mushola, dan mengumpulkan sampah yang berserakan menjadi pembiasaan pembentukan perilaku tanggungjawab dan disiplin bagi anak. Semua sivitas sekolah ikut berpartisipasi dalam kegiatan ini. Oleh karena itu, semua siswa bisa termotivasi untuk melakukan kegiatan yang sama sebagaimana diungkapkan CW 2 berikut ini.

"Keikut sertaan guru dalam pelaksanaan jum'at berkah yaitu membantu siswa gotong royong, dan bersedekah."

Sedangkan untuk jum'at sedekah dilakukan dengan mengeluarkan sesuatu yang kita punya (harta) untuk kepentingan tertentu. Siswa menyumbangkan uang seikhlasnya untuk membantu teman yang kemalangan atau terkena musibah. Misalnya teman tersebut sakit atau terkena bencana alam. Selain itu, juga ada kegiatan terprogram seperti memberi sedekah kepada panti asuhan dan bakti sosial. Tujuan dari kegiatan ini adalah siswa dididik dan dibiasakan untuk berperilaku terpuji. Berbuat baik untuk sesama mahluk hidup menjadi hal yang utama agar terhindar dari sifat buruk. Dampak dari pembiasaan sedekah dilaporkan sebuah studi dapat meningkatkan kecerdasan spiritual anak (Sari \& Yulianawati, 2017). Dalam studi tersebut dijelaskan bahwa sedekah tidak selalu harus berupa uang atau material. Anak dapat diajarkan sedekah dalam berbagai bentuk kebaikan seperti halnya tersenyum dan mengucap salam ketika bertemu orang lain, ketika melihat hewan (yang tidak membahayakan) sedang lapar hendaknya diberi makan dan minum, dan keitka melihat tanaman layu diberi air.

Dua kegiatan pada hari Jumat tersebut secara tidak langsung memberi pengertian pada siswa bahwa dalam kehidupan kita membutuhkan sikap untuk saling bekerjasama, tolong menolong, empati, tanggungjawab, mandiri, peduli lingkungan, dan disiplin sehingga terbentuk lah kesadaran diri seseorang. Selain itu ada beberapa jenis kegiatan budaya sekolah yang umum di lakukan yaitu upacara bendera setiap senin pagi, Sholat dhuha dan Sholat dzuhur.

Hasil implementasi nilai karakter ini diperkuat oleh studi terdahulu yang menyatakan bahwa lingkungan sebaiknya menekankan pada upaya pencegahan dan intervensi untuk mencegah adanya perilaku bermasalah dengan beralih dari model manajemen perilaku ke model pengembangan perilaku yang dimediasi (White \& Shin, 2016). Model manajemen perilaku dilakukan dengan memberikan pemahaman pada siswa tentang berbagai nilai moral dan karakter. Mereka akan diberikan reward atau penghargaan seperti stiker, pujian, dan hadiah jika melakukan perilaku terpuji. Sedangkan pengembangan perilaku yang dimediasi dilakukan cara mengajak anak untuk melakukan program kegiatan yang secara tidak langsung ada karakter yang dapat mereka pelajari di dalamnya. Jadi tidak hanya sekedar teori dengan guru memberi tahu mana perilaku baik dan tidak baik, namun anak dapat secara langsung melihat orang dewasa di sekitarnya dan ikut melakukan. Dengan demikian, anak tidak akan melakukan tindakan baik hanya karena ingin memperoleh sesuatu. Perilaku dengan nilai positif akan anak lakukan dengan ikhlas dan tulus dari dalam hati. Inilah yang akan menjadi tantangan bagi setiap guru dan orangtua dalam pendidikan karakter. Ketekunan dan motivasi yang kuat untuk melahirkan generasi yang hebat dan berkaraker dibutuhkan secara konsisten dan berkelanjutan.

\section{Nilai Karakter yang Ditanamkan pada Siswa Madrasah Ibtidaiyah}

Guru dan kepala sekolah mengungkapkan bahwa nilai karakter yang terintegrasi dalam program budaya sekolah yakni tanggungjawab, membantu orang lain, memiliki kemandirian, dan peduli lingkungan. Pertama, anak dibiasakan untuk menyelesaikan setiap tugas yang diberikan guru sampai selesai (bentuk tanggungjawab) meskipun terkadang 
sambil dilakukan dengan tidak serius atau main-main sebagaimana diungkapkan oleh CW 1 berikut ini:

"Sudah, tapi tidak semuanya. Karena masih ada siswa yang lalai dalam membuat tugas dan lali dalam menjaga kebersihan yang diberikan oleh gurunya. Misalnya: Tidak membuat tugas sesuai yang diarahkan oleh guru, bermain-main saat diberi kegiatan membersihkan lingkungan."

Senada dengan studi terdahulu yang menyatakan bahwa anak mampu menerima tanggung jawab sejak usia dini melalui praktek pengajaran khusus dan penyediaan lingkungan yang dapat memfasilitasi hal tersebut (Severinsen, 2014). Ketika guru memberikan tugas kepada anak, mereka akan mencari jalan terbaik untuk menyelesaikannya. Jika siswa menggunakan peralatan sekolah yang mereka bawa untuk menyelesaikan tugas tersebut, maka mereka juga belajar bertanggungjawab untuk menjaga agar tidak hilang. Dengan demikian, siswa akan lebih mandiri dalam bertanggungjawab atas diri dan tindakan mereka sendiri.

Sementara itu, guru menyatakan bahwa siswa kelas 3 di madsrash ibtidaiyah masih ada yang sering bermain-main tidak serius ketika mengerjakan tugas. Hasil ini bertentangan dengan studi terdahulu yang menyatakan bahwa anak kelas rendah (kelas 1-3) usia sekolah dasar lebih taat pada aturan dan memiliki pengendalian diri yang baik daripada anak kelas atas (kelas 4-6) (Huo \& Xie, 2021). Dalam penelitian tersebut, anak kelas atas digambarkan sebagai anak pemberontak. Kemandirian yang semakin terbentuk dan inisiatif semakin berkembang menyebabkan anak kelas atas ingin menunjukkan ide dan pemikirannya sendiri. Mereka tidak selalu mendengarkan apa yang guru katakan seperti ketika berada di kelas rendah. Guru merasa bahwa pengajaran karakter menjadi sangat sulit dilakukan. Perbedaan hasil ini bisa dijelaskan oleh fakta bahwa anak kelas rendah sebenarnya masih termasuk dalam kategori anak usia dini dimana mereka masih senang bermain. Proses belajar yang seharusnya mereka terima sebaiknya memang menggunakan metode bermain agar lebih mudah diterima anak. Sayangnya, proses pendidikan di Indonesia kurang memperhatikan hal ini. Anak sudah harus duduk dan menulis dengan tenang seperti orang dewasa sejak masuk kelas satu sekolah dasar.

Kedua, siswa dibiasakan untuk berempati terhadap oranglain. Jika ada teman yang terkena musibah, maka guru mengarahkan untuk saling menolong. Mereka secara gotongroyong mengumpulkan dana setiap satu minggu sekali dalam kegaitan Jumat Sedekah. Dana tersebut nantinya akan diberikan pada anak yang mengalami musibah atau sakit. Guru mengajak anak untuk menjenguk teman yang sakit jika tidak masuk minimal 4 hari. Pembiasaan sikap empati dan peduli terhadap orang lain secara tidak langsung merupakan upaya guru untuk menstimulasi hubungan interpersonal anak. Studi terdahulu menyatakan bahwa daripada mengajarkan tentang karakter apa yang diinginkan, pendidikan karakter pada anak perlu lebih memperhatikan hubungan interpersonal (Bates, 2019). Hal ini bermakna bahwa pendidikan karakter tidak terbatas pada lingkungan sekolah. Guru dapat mengajak anak untuk mengunjungi teman yang sakit, berkunjung ke panti asuhan dan panti jompo. Melalui kegiatan tersebut anak dapat mengembangkan kemampuan interpersonalnya untuk memahami kondisi orang lain dan membayangkan bagaimana jika kondisi tersebut terjadi padanya.

Ketiga, sikap mandiri tampak pada jadwal piket kebersihan kelas yang sudah tersusun di dinding kelas. Tanpa peringatan dari guru, anak-anak sudah tahu bahwa hari ini adalah gilirannya untuk membersihkan kelas. Kemandirian merupakan salah satu keterampilan hidup yang wajib dikuasai oleh anak. Guru dapat menstimulasi kemandirian dengan cara memberi kesempatan pada anak untuk memutuskan apa yang akan dia lakukan, memberi dukungan dan pembicaraan terbuka, menentukan batasan yang jelas, menindaklanjuti, dan memberinya dan memberinya tanggungjawab (Stevenson, 2017) Kepercayaan dari orang 
dewasa bahwa anak bisa melakukannya sendiri merupakan dukungan bagi anak untuk belajar arti mandiri.

Keempat, siswa dibiasakan untuk menyayangi lingkungan dengan tidak membuang sampah sembarangan. Sekolah menyediakan bak sampah pada setiap kelas dan sudut ruangan. Tidak mudah mengajak anak untuk melakukan kegiatan sederhana ini karena guru masih menemukan beberapa siswa membuangnya sembarangan. Jika ada yang membuang sampah tidak pada temapatnya, guru dan teman lain langsung mengingatkan akan cinta kebersihan sebagaimana diungkapkan oleh CW2 berikut ini.

"Tidak semua siswa melaksankan kepedulian lingkungan masih saja beberapa siswa membuang sampah sembarangan."

Kegiatan membersihkan kelas dan membuang sampah pada tempatnya dalam studi terdahulu disebutkan termasuk dalam proses untuk menjaga ketahanan lingkungan (environmental sustainability) (Ghosn-Chelala \& Akar, 2021). Sayangnya, studi tersebut mengungkapkan jika guru yang menjadi partisipan ketahanan lingkungan yang diajarkan pada siswa terbatas pada pengetahuan yang ditetapkan dalam kurikulum nasional. Siswa belum dipoisisikan sebagai salah satu bagian dari sistem yang turut serta berkontribusi terhadap ketahanan lingkungan. Sementra itu, hasil penelitian kami menunjukkan bahwa sekolah sudah memasukkan program ini dalam kurikulum. Ini berarti sekolah sudah memikirkan dampak yang akan anak-anak berikan terhadap keberlanjutan kondisi lingkungan. Siswa tidak hanya diajarkan tentang kelestarian alam pada mata pelajaran IPA atau IPS tetapi diajak untuk langsung mengimplementasikannya.

Selanjutnya, guru memberikan umpan balik terhadap perilaku yang kurang tepat dilakukan anak seperti tidak membuang sampah pada tempatnya. Guru langsung memberi teguran pada yang bersangkutan agar membuang sampah pda tempatnya. Hasil ini sesuai dengan hasil penelitian terdahulu yang menyatakan bahwa guru sebaiknya memberikan umpan balik secara individual kepada anak (Singh \& Mueller, 2021). Proses ini lebih efektif daripada guru memberikan umpan balik secara kelompok. Ketika memberikan umpan balik terhadpa perilaku siswa, guru dapat dilakukan secara verbal maupun nonverbal (contoh: ekspresi wajah, memberi aba-aba, dan gestur tubuh). Dengan adanya umpan balik, anak merasa diperhatikan oleh guru. Oleh karena itu, mereka akan semakin mandiri dan percaya diri karena merasa didukung penuh oleh guru terutama jika melakukan tindakan yang positif dan bermanfaat.

\section{Hambatan Pelaksanaan Program}

Faktor penghambat dalam pelaksanaan pendidikan karakter di madrasah ibtidaiyah adalah guru yang memiliki sedikit waktu di dalam kelas dan adanya orang tua yang tidak peduli. Kondisi ini bertentangan dengan hasil penelitian terdahulu yang menyatakan bahwa kesuksesan pendidikan karakter dipengaruhi oleh lingkungan yang berada di sekitar anak termasuk guru, orangtua, dan masyarakat (Yang, 2021). Dalam studi tersebut dijelaskan pendidikan karakter di sekolah hanyalah salah satu proses interaksi yang terjadi dalam satu tingkatan ekologi. Keluarga, teman, dan masyarakat di sekitar anak berpengaruh terhadap pola pikir dan tindakan yang dilakukan anak. Tanpa keterlibatan dari tingkatan ekologi yang lain, maka pendidikan karakter tidak akan memberikan dampak apapun untuk anak.

Keberhasilan pendidikan karakter diperlukan keterlibatan dari semua pihak. Pendidikan di keluarga merupakan awalan, sekolah sebagai pusat, sedangkan pemerintah dan masyarakat sebagai pendukung (Eryong \& Li, 2021). Ketika proses berlangsung, keluarga seharusnya menjadikan diri sebagai contoh yang baik. Mereka adalah pendidikan dan guru pertama bagi anak. Keterlibatan orangtua pada pendidikan dan kesadaran moral membuat kebiasaan dan perilaku anak akan terbentuk dengan baik. Sementara itu, sekolah perlu memberikan pelatihan tentang pendidikan karakter pada semua staf yang ada dan memberikan strategi yang tepat untuk menjalin komunikasi dan hubungan yang baik dengan orangtua. Terbatasnya guru dan orangtua sebagai narasumber menjadi salah satu kelemahan 
dalam penelitian kami. Melibatkan semua guru dari kelas rendah dan beberapa orangtua dapat memperkaya informasi yang diperoleh dalam penerapan pendidikan karakter termasuk berbagai faktor yang mendukung dan menghambat pelaksanaannya. Selain itu, budaya sekolah yang kami gali informasinya hanya sebatas pada program Jumat Berkah. Budaya sekolah lain yang sudah dilakukan oleh madrasah ibtidaiyah penting dicari tahu sehingga dapat digunakan sebagai referensi untuk menunjukkan perbedaan sistem pendidikan di madrasah ibtidaiyah dengan sekolah negeri.

\section{SIMPULAN}

Pendidikan karakter dapat diintegrasikan dengan budaya sekolah melalui kegiatan yang dilakukan secara periodik atau rutin. Salah satu yang sudah dilakukan oleh sekolah adalah kegiatan Jumat Berkah yang di dalamnya anak akan belajar sikap tanggungjawab, membantu orang lain, memiliki kemandirian, dan peduli lingkungan. Keterlibatan siswa dalam kegiatan tersebut mengindikasikan bahwa pendidikan karakter tidak hanya sebatas teori namun langsung dalam bentuk praktek. Implementasi hasil penelitian ini adalah dapat digunakan oleh sekolah lain sebagai referensi untuk menerapkan pendidikan karakter dengan program budaya sekolah. Peneliti selanjutnya juga dapat meninjau kelemahan penelitian kami untuk melakukan penelitian lanjutan.

\section{UCAPAN TERIMA KASIH}

Peneliti ucapkan terima kasih kepada seluruh pihak yang berkontribusi dan berpartisipasi dalam penelitian ini, sampai dengan selesai penelitian dan publishnya artikel ini. Semoga tulisan ini dapat bermanfaat bagi mahasiswa, guru, peneliti selanjutnya dan bagi pembaca.

\section{DAFTAR PUSTAKA}

Agustini, S. (2015). Building Students Character Through Culture School In. Jurnal Pendidikan Karakter, 5(2), 219-228. https://media.neliti.com/media/publications/122482-IDimplementasi-pendidikan-karakter-melalui.pdf

Anggraini, M. S. A. (2017). Implementasi Pendidikan Karakter Melalui Budaya Sekolah di SD N Kota Gede 3 Yogyakarta Tahun Ajaran 2016/2017. Trihayu: Jurnal Pendidikan KeSD-An, 3(3), 151-158.

Arifin. (2019). Penumbuhan Budi Pekerti Melalui Penguatan Budaya Sekolah Di SMA Negeri 5 Kupang. Jurnal Ilmiah UPT P2M STKIP Siliwangi. https:// doi.org/10.22460/p2m.v6i1p1-13.1247

Bates, A. (2019). Character Education And The 'Priority of Recognition.' Cambridge Journal of Education, 49(6), 695-710. https://doi.org/10.1080/0305764X.2019.1590529 https:// doi.org/10.1080/0305764X.2019.1590529

Eryong, X., \& Li, J. (2021). What is The Ultimate Education Task in China? Exploring "Strengthen Moral Education for Cultivating People" ("Li De Shu Ren"). Educational $\begin{array}{llll}\text { Philosophy and } \quad \text { Theory, } & \text { 128-139. }\end{array}$ https:// doi.org/10.1080/00131857.2020.1754539

Furkan, N. (2013). Pendidikan Karakter Melalui Budaya Sekolah. Yogyakarta: Magnum Pustaka Utama.

Ghosn-Chelala, M., \& Akar, B. (2021). Citizenship Education for Environmental Sustainability In Lebanon: Public School Teachers' Understandings and Approaches. Environmental Education Research, 27(3), 366-381. https:// doi.org/10.1080/13504622.2021.1879024

Huo, Y., \& Xie, J. (2021). Exploring the Issue of a Lack of Cohesion in Moral Education: an Empirical Study in Chinese Primary And Secondary Schools. Journal of Moral Education, 50(4), 512-528. https:// doi.org/10.1080/03057240.2020.1814710 
Jhon, W., Sugito, Zubaidah, E., \& Mustadi, A. (2021). Challenges in the Implementation of Character Education in Elementary School: Experience From Indonesia. İlköğretim Online, 20(1), 1351-1363. https:// doi.org/10.17051/ilkonline.2021.01.130

Khairudin, M. (2013). Character Education Through School Culture Development In Integrated Islamic School Salman Al Farisi Yogyakarta. Jurnal Pendidikan Karakter, III(1), 77-86.

Kurniawan, F. (2017). Analisis Penerapan Budaya Sekolah Dalam Pembentukan Karakter Disiplin Siswa Di Kelas III SD N 2 Blunyahan. Universitas Negeri Yogyakarta.

Lusyanti, D., Susilawati, W. O., \& Prananda, G. (2020). Analisis Implementasi Pendidikan Karakter Melalui Budaya Sekolah Di SDN 058/II Sri Mulya. Jurnal Dharma PGSD, 1.

Muhtar, T., \& Dallyono, R. (2020). Character Education From The Perspectives Of Elementary School Physical Education Teachers. Cakrawala Pendidikan, 39(2), 395-408. https://doi.org/10.21831/cp.v39i2.30647

Norianda, N., Dewantara, J. A., \& Sulistyarini. (2021). Internalisasi Nilai Dan Karakter Melalui Budaya Sekolah Studi Budaya Jumat Berkah. Jurnal Pendidikan Nilai Dan Pembangunan Karakter, 5. https:// doi.org/10.21776/ub.waskita.2021.005.01.4

Prasanti, D., \& Fitrianti, D. R. (2018). Pembentukan Karakter Anak Usia Dini: Keluarga, Sekolah, Dan Komunitas. Pembentukan Anak Usia Dini: Keluarga, Sekolah, Dan Komunitas, 2(1), 15. https://doi.org/10.31004/obsesi.v2i1.2

Rahayu, D. W., \& Taufiq, M. (2020). Analisis Pendidikan Karakter Melalui Living Values Education (LVE) Di Sekolah Dasar. Jurnal Inovasi Penelitian, 1.

Riadi, Ak. (2018). Membangun Karakter Siswa Melalui Budaya Sekolah. Al-Falah: Jurnal Ilmiah Keislaman Dan Kemasyarakatan, 18(2), 265-281.

Sari, A. C., \& Yulianawati, T. (2017). Sedekah Sebagai Media Spiritual Anak Usia Dini. Thufula STAIN Kudus, 05(1), 94-96.

Severinsen, G. (2014). Teaching Personal And Social Responsibility To Juniors Through Physical Education. Asia-Pacific Journal of Health, Sport and Physical Education, 5(1), 83-100. https:// doi.org/10.1080/18377122.2014.867793

Shohel, M. M. C., \& Howes, A. J. (2018). The Relevance Of Formal And Nonformal Primary Education In Relation To Health, Well-Being And Environmental Awareness: Bangladeshi Pupils' Perspectives In The Rural Contexts. International Journal of Qualitative Studies on Health and Well-Being, 13(1). https://doi.org/10.1080/17482631.2018.1554022

Singh, K., \& Mueller, J. (2021). Taking A Nuanced View Of The Role Of Teacher Feedback In The Elementary Classroom. Teachers and Teaching: Theory and Practice, 27(1-4), 95115. https:// doi.org/10.1080/13540602.2021.1933415

Stevenson, B. (2017). Children's Independence: A Conceptual Argument For Connecting The Conduct Of Everyday Life And Learning In Finland. Children's Geographies, 15(4), 439-451. https:/ / doi.org/10.1080/14733285.2016.1271942

Suhadisiwi, I. (2018). Panduan Praktis Implementasi Penguatan Pendidikan Karakter (PPK) Berbasis Budaya Sekolah. Jakarta: Pusat Analisis dan Sinkronisasi Kebijakan (PASKA).

White, R., \& Shin, T. S. (2016). School-Wide Mediated Prosocial Development: Applying A Sociocultural Understanding To Inclusive Practice And Character Education. Multicultural Education Review, 8(4), 213-229. https://doi.org/10.1080/2005615X.2016.1237418

Yang, C. (2021). Moral Education In Mainland China Today: A Bio-Ecological Systems Analysis. Journal of Moral Education, 50(4), 529-543. https://doi.org/10.1080/03057240.2020.1847054

Yudhawardhana, A. N. (2017). Kegiatan Jumat Bersih Di Lingkungan Sekolah Sebagai Bentuk Sikap Gotong Royong Dalam Membentuk Karakter Siswa. Jurnal Prosiding SENASGABUD. 